KS. ROMAN SZEWCZYK

Uniwersytet Warmińsko-Mazurski w Olsztynie

\title{
POZYCJA PRAWNA LEGATÓW BISKUPA RZYMU
}

Treść: - 1. Historyczny rozwój instytucji legata papieskiego. - 2. Prawo międzynarodowe a Legaci Biskupa Rzymskiego. - 3. Pojęcie i rodzaje legatów papieskich. - 4. Zadania legatów wobec kościoła partykularnego. - 5. Zadania legatów wobec władz państwowych i organizacji międzynarodowych.

\section{Historyczny rozwój instytucji legata papieskiego}

Od początku dziejów Kościoła - z ustanowienia Chrystusa - Biskup Rzymu stał na jego czele. Nowo powstała wspólnota uczniów Chrystusa szybko się powiększała i Kościół Powszechny zarysowywał coraz to nowe granice. Rozwój Kościoła, wzrost liczby wyznawców i pojawienie się nowych problemów do rozwiązania uniemożliwiały Biskupowi Rzymu osobistą obecność w kościołach lokalnych, stąd też posyłał on do nich swoich przedstawicieli. Już historia pierwotnego Kościoła dostarcza nam przykłady takiego posłannictwa ${ }^{1}$.

Pierwszym ważnym źródłem mówiącym o praktyce wysyłania swoich przedstawicieli przez Biskupa Rzymu jest list papieża Klemensa Rzymskiego do Koryntian. Klemens Rzymski pisze: „Posyłamy wam mężów pewnych i mądrych, których życie wśród nas od młodości aż do późnego wieku było bez zarzutu. Niech oni będą świadkami między wami a nami"’2. Kolejne źródła wysyłania przez papieży swoich reprezentantów znajdujemy przy okazji pierwszych synodów i sobo-

\footnotetext{
1 ,Wtedy Apostołowie i starsi wraz z całym Kościołem postanowili wybrać ludzi przodujących wśród braci: Judę, zwanego Barsabas i Sylasa i wysłać do Antiochii razem z Barnabą i Pawłem”. Dz 15,22.

${ }^{2}$ Klemens Rzymski, List do Koryntian, LXIII, 3 w: Listy katolickie. Przekład z oryginału - wstęp - komentarz, oprac. F. Gryglewicz, Poznań 1959, s. 81.
} 
rów, w Nicei w 325 r., w Konstantynopolu w 381 r., w Efezie w 431 r., w Chalcedonie w 451 r. Przedstawiciele Biskupa Rzymskiego wywodzili się z jego najbliższego otoczenia, z kleru rzymskiego, a potem italskiego i mogli przewodniczyć obradom oraz składać swoje podpisy na uchwalonych dokumentach ${ }^{3}$.

W IV wieku pojawia się pierwsze określenie wysłannika Biskupa Rzymu, nazywano ich wikariuszami apostolskimi. Byli to biskupi diecezjalni, którzy z mandatu papieskiego czuwali nad prowincjami kościelnymi, zastępując w nich papieża. Do ich zadań należało m.in. przewodniczyć synodom, konsekrować metropolitów, rozstrzygać spory powstałe pomiędzy biskupami oraz przesyłać informacje o sytuacji kościołów lokalnych do Rzymu ${ }^{4}$. Z upływem czasu, w średniowieczu, funkcja ta przerodziła się w legata urodzonego tzw. legatus natus, biskupi ważniejszych stolic biskupich uzyskiwali część jurysdykcji papieskiej i obowiązek składania sprawozdań z wypełnionych obowiązków ${ }^{5}$.

Na początku V wieku pojawia się drugie określenie wysłannika Biskupa Rzymu, na Synodzie w Kartaginie został on nazwany legatus a latere. Tytuł ten oznaczał wysłannika, który w imieniu papieża musiał załatwić bieżące sprawy, a po ich załatwieniu tracił władzę 6 .

Kolejnym tytułem wysłanników papieża od V wieku byli apokryzjariusze $e^{7}$, przedstawiciele przy dworze cesarskim w Konstantynopo-

3 Por. F. Pasternak, Posoborowa odnowa instytucji legatów papieskich, Prawo Kanoniczne 22(1979) n. 1-2, s. 34.

${ }^{4}$ Por. E. SzTafrowski, Wspótpracownicy Papieża w pasterskim posługiwaniu, Warszawa 1979, s. 162.

5 Pierwszym takim przedstawicielem był wysłany przez papieża Damazego I biskup Ascholius z Tesalonik do wschodniej Illirii. Por. F. PAsternak, Posoborowa ..., s. 35.

${ }^{6}$ Por. Tamże, s. 162; M. Żurkowski, O duchowieństwie w szczególności. Czesśś I Hierarchiczne funkcje zarządzania Kościołem, Warszawa 1970, s. 181-182.

7 „Apokryzjariusz (gr. Apokrisiarios, łac. Responsalis przynoszący odpowiedź), urząd w dyplomacji bizantyjskiej o charakterze cywilnym, wojskowym lub kościelnym. W ostatnim wypadku była to forma stałego przedstawicielstwa bpa przy metropolicie, metropolity przy patriarsze bądź też patriarchów lub papieży przy dworze cesarskim w Konstantynopolu. Urząd ten powstał w połowie V w. i odpowiadał dzisiejszej nuncjaturze (...) Pierwszym papieskim apokryzjariuszem w Konstantynopolu 
lu. Z zasady nie posiadali oni jurysdykcji, tylko wykonywali funkcje i zadania dyplomatyczne i kościelne. Okres średniowiecza umocnił pozycję wysłannika papieskiego, od tej pory oni przewodniczyli synodom regionalnym i lokalnym, którym nadano nazwę synody legackie oraz rozwiązywali wszystkie problemy powstałe w kościołach partykularnych ${ }^{8}$.

IX wiek przynosi nową jakość w działalności legatów papieskich. Zostali oni nazwani legati missi i byli wysyłani do władców świeckich różnych krajów, aby strzec spraw Kościoła. Papież Grzegorz VII nazwał ich nuntii a latere Apostolicae Sedis lub nuntii ex latere nostro. Właśnie XIII wiek przynosi powstanie urzędu nuncjusza apostolskiego, który w swojej osobie obejmował zadania apokryzjariusza oraz nuntio a latere nostro. Wśród tych legatów znajdujemy również kardynałów, którzy posiadali szerokie uprawnienia do wprowadzania reformy kościelnej i nawet gdy na terenie ich posłania byli obecni legati nati, działali oni niezależnie od nich ${ }^{9}$. Dzięki dużym uprawnieniom posiadali szczególną pozycję wobec rządzących krajem. Ich działalność i funkcja nie kończyła się wraz ze śmiercią papieża, w zastępstwie papieża rozgrzeszali z cenzur zarezerwowanych papieżowi, sprawowali władzę nad wyjętymi spod władzy biskupa, potwierdzali wybór arcybiskupów i biskupów, dyspensowali od przeszkód małżeńskich oraz nadawali beneficja ${ }^{10}$. Niestety, ich wielka władza i jej nadużycie często stawało się powodem konfliktów z miejscowymi ordynariuszami oraz władcami świeckimi. Na przełomie XI/XIV niektórzy królowie nie wpuszczają legatów, są im nieprzychylni, a nawet ich prześladują ${ }^{11}$.

przy dworze cesarza Marcjana i Pulcherii był biskup Julian z Chios, mianowany przez Papieża Leona Wielkiego (...)”. B. Kumor, Apokryzjariusz, w: Encyklopedia Katolicka, t. 1, Lublin 1985, k. 770-771.

8 Por. W. GóRALSKI, Statuty synodalne legata Jakuba z Leodium, Prawo Kanoniczne 27(1984) n. 3-4, s. 150.

9 Por. Z Grocholewski, Dyplomacja Stolicy Apostolskiej, w: Encyklopedia Katolicka, t. 4, Lublin 1983, k. 428.

${ }^{10}$ Por. F. Pasternak, Posoborowa..., s. 36.

${ }^{11}$ Por. E. Sztafrowski, Wspótpracownicy..., s. 159. 
Obok wyżej omówionych urzędów na przestrzeni XII-XIV wieku znajdujemy przedstawicieli Stolicy Apostolskiej, którzy pełnili niektóre funkcje dyplomatyczne. Wśród nich są kolektorzy oraz administratorzy na rzecz Stolicy Apostolskiej ${ }^{12}$. Te urzędy pojawiają się, gdy rozbudowywano centralny system władzy w Kościele wraz z podstawami prawnymi administracji, gdy rozwijała się polityka finansowa oraz interwencje Rzymu w kościołach lokalnych. Kolektor cieszył się tylko częściowo władzą legata, miał za zadanie wynajdywać źródła dochodu dla Stolicy Apostolskiej lub rozwiązywać problemy polityczne ${ }^{13}$.

Pomimo iż czas średniowiecza nie należał do okresu stabilnego omawianej materii, to jednak próbowano uregulować działania legatów papieskich. Taką próbę podjęto na Soborze Laterańskim IV i Soborze Liońskim I. Konstytucja Procurationis quae visitationis Soboru Laterańskiego ograniczyła władzę i uprawnienia legatów, nie mogli oni obciążać finansowo kościoła lokalnego ani domagać się świadczeń $\mathrm{z}$ racji wizytacji ${ }^{14}$. Natomiast konstytucja Officii nostri debitum Soboru Liońskiego ograniczyła władzę legata zabraniając mu nadawania beneficjów, z wyjątkiem kardynałów ${ }^{15}$.

W XV wieku wraz z pojawieniem się nowych organizmów państwowych nastąpiła stabilizacja w dyplomacji kościelnej i państwowej. Ze strony Kościoła widzimy rezygnację z wielu pól właściwych dla władzy państwowej i ukierunkowanie się na sprawy stosunków Ko-

${ }^{12}$ „Kolektor (łac. zbieracz jałmużny; collector generalia gł. kwestarz, kościelny urzędnik kancelaryjny (notarius camera, poenitentiarias domini papae) zbierający w imieniu papieża kolekty (jałmużnik), świadczenia na rzecz skarbu papieskiego (annaty) i daniny z beneficjów (dziesięcina papieska), zajmujący ważne stanowisko w hierarchii kościelnej (legat, ordynariusz diecezji lub posiadacz kanonii) (...) Kolektor zazwyczaj dobrze znał miejscowe zwyczaje, teren, ludzi i ich problemy oraz sprawy skarbowe Stolicy Apostolskiej. Dzięki swej władzy był niezależny od miejscowych dygnitarzy. Często pełnił równocześnie jakąś funkcję w kancelarii papieskiej (...) S. Tymosz, Kolektor, w Encyklopedia Katolicka, t. 9, Lublin 2002, k. 341-342.

${ }^{13}$ Por. tamże, k. 341.

${ }^{14}$ Por. Sobór Laterański IV, Konstytucja Procurationis quae visitationis, w: Dokumenty Soborów Powszechnych, t. II, Kraków 2003, s. 273.

${ }^{15}$ Por. Sobór LioŃski I, Konstytucja Officii nos tri debitum, w: Dokumenty Soborów Powszechnych, t. II, Kraków 2003, s. 355. 
ścioła wobec określonego państwa. W tym też czasie powstają pierwsze przedstawicielstwa Stolicy Apostolskiej, nazywane nuncjaturami. Pierwsza stała misja dyplomatyczna powstała w Hiszpanii w 1492 r., a potem w Wenecji w 1550 r., w Como w 1510 r, we Francji, Niemczech i Portugalii w $1513 \mathrm{rr}^{16}$. Trwałe fundamenty dyplomacja Stolicy Apostolskiej uzyskała za papieża Leona X i na Soborze Laterańskim V. W uchwałach soborowych zawarto przepisy dotyczące działalności legatów ${ }^{17}$.

Po krótkim okresie stabilizacji nadeszła reformacja, która wysiłki całej dyplomacji skupiła na zahamowaniu rozwoju i skutków reformacji, odsuwając działalność polityczną na drugi plan. Po Soborze Trydenckim postanowiono ograniczyć uprawnienie legatów do zajmowania się sprawami kościołów partykularnych, przywracając tym samym biskupom diecezjalnym zarząd i odpowiedzialność za diecezję. Legaci zaś mogli rozstrzygać sprawy sądowe w najwyższej instancji oraz mogli prowadzić procesy informacyjne dla kandydatów na biskupów ${ }^{18}$.

Za czasów pontyfikatu papieża Grzegorza XIII wykształciły się struktury nuncjatury apostolskiej oraz została wprowadzona klasyfikacja legatów papieskich. Papież Grzegorz XIII rozróżnił pojęcie urzędu legata, którym był kardynał wysłany w roli ambasadora nadzwyczajnego od urzędu nuncjusza, który był stałym przedstawicielem na dworze władcy lub w państwie. Ponadto ustanowił klasyfikację pomiędzy nuncjaturami, określił uposażenie dyplomatów i kierowników misji dyplomatycznych, których podniósł do godności biskupiej ${ }^{19}$. Zasługą Papieża Grzegorza XIII było bardzo dokładne określenie pola działalności legatów z przewodnią dewizą pierwszeństwa spraw kościelnych nad politycznymi. Od tej pory nuncjusz był biskupem lub arcybiskupem, który miał obowiązek informowania Biskupa Rzymu o sytuacji Kościoła w danym państwie, o biskupach, innych osobistościach dane-

\footnotetext{
${ }^{16}$ Por. Z. Grocholewski, Dyplomacja ..., k. 428.

${ }^{17}$ Por. Sobór Laterański V, Konstytucja De cardinalibus, n. II/B, w: Dokumenty Soborów Powszechnych, t. IV, Kraków 2004, s. 95.

${ }^{18}$ Por. T. PieroneK, Nuncjusz, osobisty reprezentant Biskupa Rzymu, Tygodnik Powszechny, n. 43(1989), s. 5.

${ }^{19}$ Por. Z. Grocholewski, Dyplomacja ..., k. 428.
} 
go kraju, o różnych aspektach życia kościelnego, politycznego i kulturalnego w danym kraju. Sprawozdania wysyłane były często, nawet co tydzień, w języku łacińskim, a gdy zachodziła określona okoliczność, mogły być szyfrowane ${ }^{20}$. Tak ustalone struktury nuncjatur oraz zadania legatów papieskich przetrwały całe wieki aż do naszych czasów bez większych zmian. Legaci Biskupa Rzymu weszli na stałe w strukturę Kościoła i stali się znakiem obecności Biskupa Rzymskiego w świecie. Nuncjusze uposażeni materialnie przez Stolicę Apostolską skutecznie troszczą się o zachowanie i rozwój wiary katolickiej, utrwalają autorytet Biskupa Rzymu, bronią nieskrępowanego wykonywania przez Kościół swojej misji oraz utrwalają pokój między narodami ${ }^{21}$.

Wieki XVII i XVIII przynoszą osłabienie aktywności dyplomatycznej Stolicy Apostolskiej. Spowodowane to było od wewnątrz Kościoła zmniejszeniem zakresu problemów dyplomacji papieskiej i ograniczeniem swojej aktywności do krajów katolickich. Zaś od strony zewnętrznej miały wpływ na to ataki ówcześnie rządzących pozostających pod wpływem wrogich Kościołowi doktryn politycznych i społecznych. Dopiero na początku XIX wieku, a dokładniej po kongresie wiedeńskim w 1815 r. nastąpiło odrodzenie dyplomacji kościelnej. $\mathrm{Na}$ kongresie wiedeńskim odtworzono Państwo Kościelne, uznano osobowość prawną Kościoła katolickiego i Stolicy Apostolskiej. Aspekt umocowania podmiotu prawa międzynarodowego, jakim jest Stolica Apostolska oraz legatów Biskupa Rzymu w prawie międzynarodowym zostanie omówiony w punkcie 2 .

W dalszym rozwoju historycznym uwidacznia się aktywna obecność Biskupa Rzymu i jego wysłanników w świecie. Powstają nowe placówki dyplomatyczne już nie tylko w państwach katolickich, ale i w państwach protestanckich i prawosławnych ${ }^{22}$. Sobór Watykański I ogłasza dogmat o nieomylności papieża i potępia zarazem błędne doktryny odnośnie do władzy papieża. Gdy papieżem zostaje Leon

${ }^{20}$ Por. M. Banaszak, Historia Kościoła Katolickiego, t. 3, Czasy nowożytne 15171758, Warszawa 1989, s. 132.

${ }^{21}$ Por. T. PieroneK, Nuncjusz ..., s. 5.

${ }^{22}$ Por. M. BanaszaK, Historia ...., s. 66. 
XIII, uzdolniony dyplomata i polityk, wzrasta autorytet Stolicy Apostolskiej. Papież Leon XIII wielokrotnie posługuje się w swoim działaniu legatami, jednocześnie zaznacza, że Biskup Rzymu ma prawo wrodzone wysyłania swoich legatów ${ }^{23}$. Następne lata uwidaczniają siłę i znaczenie dyplomacji watykańskiej, jej zaangażowanie w mediacje pokojowe, pomagają w rozwiązywaniu konfliktów pomiędzy zwaśnionymi stronami. Wzrasta liczba przedstawicielstw Stolicy Apostolskiej w świecie ${ }^{24}$.

Doniosłe znaczenie dla instytucji legata papieskiego przyniósł rok 1917, w którym ogłoszono pierwszy w Kościele Kodeks Prawa Kanonicznego. W tym Kodeksie oddzielny rozdział został poświęcony „De legatis Romani Pontificis”25. Kanony kodeksu od 265-270 przedstawiają urząd legatów papieskich. Biskup Rzymu ma własne i wrodzone prawo do wysyłania swoich legatów (kan. 265), wśród których znajdujemy legata a latere oraz legata qui mittuntur. Mogą oni mieć tytuły nuncjusza, internuncjusza lub delegata apostolskiego (kan. 266). Do głównych ich zadań należy utrzymywanie stosunków pomiędzy Stolicą Apostolską a rządami świeckimi państw oraz czuwanie nad kościołem lokalnym (kan. 267). Legaci nie tracą swojego urzędu na skutek wakansu Stolicy Apostolskiej, chyba że zarządzono inaczej. Ich mandat wygasa poprzez odwołanie, przyjęcie zrzeczenia lub po wykonaniu zadania (kan. 268). W realizacji swojego posłannictwa nie mogą wpływać na jurysdykcję biskupa miejscowego (kan. 269).

W czasach I i II wojny światowej działalność legatów papieskich skupia się na wysiłkach prowadzących do zaprzestania konfliktów wojennych oraz niesienia pomocy ofiarom wojen.

${ }^{23}$ Por. Claeys-Bouuaert, Lègat du Pape, w: Dictionaire de Droit Canonique, t. 6, Paris 1957, k. 372; E. Sztafrowski, Współpracownicy..., s. 161.

${ }^{24}$ Por. Z. Grocholewski, Dyplomacja..., k. 428-429.

${ }^{25}$ Kodeks Prawa Kanonicznego promulgował Benedykt XV bullą Providentissima Mater Ecclesia z dnia 27 maja 1917r. Urzędowa nazwa brzmi Codex Iuris Canonici, Pii X Pontificis Maximi iussu digestus, Benedicti XV auctoritate promulgatus. Por.

T. Pawluk, Prawo kanoniczne według Kodeksu Jana Pawła II. T. I. Zagadnienia wstęne i normy ogólne. Olsztyn 1985, s. 110. 


\section{Prawo międzynarodowe a legaci Biskupa Rzymskiego}

W ostatnich dziesięcioleciach obserwujemy intensywny rozwój stosunków międzynarodowych, powstały ważne organizacje międzynarodowe skupiające wiele państw i wpływające na ich życie. Na płaszczyźnie prawa międzynarodowego Stolica Apostolska działa i odgrywa taką samą rolę, jak inny podmiot tego prawa. Przez całe wieki Stolica Apostolska wywierała właściwy wpływ na formowanie zasad prawa międzynarodowego $i$ jego norm, a potem skupiała się na tematyce etycznej i prawnej, zachowując daleko posuniętą dyskrecję wobec technicznych punktów widzenia i z dystansem traktując kwestie dotyczące spraw politycznych czy militarnych ${ }^{26}$. Aktywnie w tym uczestniczą legaci Biskupa Rzymu, któremu na kongresie wiedeńskim w 1815 r. zostało potwierdzone prawo legacji. Wielowiekowa obecność Biskupa Rzymu na arenie międzynarodowej została doceniona przez kongres i legatom papieskim przyznano przywilej pierwszeństwa, w konsekwencji czego nuncjusz pełni funkcje dziekana korpusu dyplomatycznego. Ten zwyczaj powierzania funkcji dziekana korpusu dyplomatycznego został usankcjonowany w Regulaminie wiedeńskim podpisanym przez przedstawicieli państw nie tylko katolickich. Od tego momentu Stolica Apostolska nawiązuje stosunki dyplomatyczne $\mathrm{z}$ coraz to większą liczbą państw ${ }^{27}$.

Uznanie legatów za przedstawicieli dyplomatycznych oraz przyznanie im funkcji dziekana korpusu dyplomatycznego odnajdujemy w Konwencji Wiedeńskiej o Stosunkach Dyplomatycznych z roku $1961^{28}$. Pomimo kodyfikacyjnego charakteru ta Konwencja nie derogowała obowiązującego prawa zwyczajowego. Stąd też wiąże ono nadal państwa, które nie są stronami konwencji i pozostałe państwa

\footnotetext{
${ }^{26}$ Por. A. CASARoli, Le Saint-Siège et la communauté internationales, La Documentation Catholique, 1682 (1975), s. 309.

${ }^{27}$ Por. T. Pawluk, Przedstawicielstwo papieskie w Kościele partykularnym i dyplomacja Stolicy Apostolskiej, PK 33(1990) n. 3-4, s. 16-17.

${ }^{28}$ Konwencja Wiedeńska o Stosunkach Dyplomatycznych, sporządzona w Wiedniu dnia 18 kwietnia 1961r., Dz.U. z 1965 r., nr. 37, poz. 232.
} 
w sprawach, które nie zostały unormowane Konwencją ${ }^{29}$. Konwencja opisuje zasady, jakie obowiązują w prawie dyplomatycznym od momentu rozpoczęcia misji dyplomatycznej aż do jej zakończenia. Wyszczególnia zadania misji dyplomatycznych. Wśród nich znajdujemy m.in. reprezentowanie swojego państwa w państwie przyjmującym, ochronę wszystkich interesów państwa wysyłającego w państwie przyjmującym oraz jego obywateli w granicach ustalonych przez prawo międzynarodowe, prowadzenie rokowań z rządem państwa przyjmującego, zapoznanie się ze wszelkimi dostępnymi legalnymi sposobami i warunkami panującymi w państwie przyjmującym i z rozwojem zachodzących w nim wydarzeń oraz przesyłanie z tego sprawozdań własnemu rządowi, aranżowanie i umacnianie przyjaznych stosunków pomiędzy państwami: wysyłającym i przyjmującym oraz rozwijanie pomiędzy nimi stosunków w dziedzinie gospodarki, kultury i nauki ${ }^{30}$.

Konwencja w art. 16 przedstawiła zasadę pierwszeństwa: „1. Szefowie misji korzystają z pierwszeństwa w obrębie swojej klasy w kolejności dat i godzin objęcia swych funkcji zgodnie z art. 13.2. Zmiany w listach uwierzytelniających szefa misji niepowodujące zmiany klasy nie wpływają na jego pierwszeństwo. 3. Niniejszy artykuł nie stoi na przeszkodzie w stosowaniu praktyki, która jest lub mogłaby być przyjęta przez państwo przyjmujące w odniesieniu do pierwszeństwa przedstawiciela Stolicy Apostolskiej" 31 . Ten artykuł potwierdza zapis Kongresu Wiedeńskiego z 1815 r. i wyraźnie mówi o zasadzie pierwszeństwa legata papieskiego pośród ambasadorów.

Pomimo że Kościół jako wspólnota religijna zachowuje odrębność struktur gospodarczych i politycznych, to prowadzi z nimi dialog instytucjonalny. Stąd też widzimy obecność przedstawicieli Biskupa Rzymu przy organizacjach międzynarodowych. Wśród organizacji międzynarodowych można wskazać ONZ, gdzie od 1964 r. jest obecny

${ }^{29}$ Por. R. Bierzanek, J. Simonides, Prawo międzynarodowe publiczne, Warszawa 1992, s. 164-165.

${ }^{30}$ Konwencja... art. 3.

${ }^{31}$ Konwencja... art. 16. 
przedstawiciel Stolicy Apostolskiejm, pełniący urząd Stałego Obserwatora ${ }^{32}$.

Zaangażowanie Stolicy Apostolskiej na polu dyplomatycznym w Europie owocuje przedstawicielstwami i nuncjaturami przy wielu organizacjach europejskich. Od zakończenia II wojny światowej Stolica Apostolska popierała procesy pokojowe i zjednoczeniowe na terenie Europy, wśród nich utworzenie Rady Europy czy podpisanie Europejskiej Wspólnoty Węgla i Stali. I choć przez całe dziesięciolecia kontakty pomiędzy Stolicą Apostolską a instytucjami unijnymi były nieformalne, to przełom przyniosło przystąpienie Stolicy Apostolskiej do Rady Współpracy Kulturalnej przy Radzie Europy. Od 10 grudnia 1970 r. został powołany obserwator Stolicy Apostolskiej jako wysłannik specjalny ${ }^{33}$.

Również od roku 1970 obecny jest Delegat Stolicy Apostolskiej przy strukturach UE. W roku 1999 papież Jan Paweł II podniósł jego status do rangi nuncjusza apostolskiego ${ }^{34}$. Jego głównymi zadaniami są: reprezentowanie Stolicy Apostolskiej, utrzymywanie bezpośrednich kontaktów z Komisją Europejską, przedstawianie stanowiska Kościoła wobec podejmowanych problemów przez Unię oraz informowanie Stolicy Apostolskiej o działalności UE ${ }^{35}$.

Zakres kontaktów i nawiązywanie stosunków dyplomatycznych nie ogranicza Stolicy Apostolskiej tylko do Europy czy instytucji europejskich. Nawiązano bardzo wiele relacji dyplomatycznych z krajami muzułmańskimi na Środkowym i Dalekim Wschodzie. Powstały w tych krajach internuncjatury, czyli poselstwa. Rozległe stosunki dyplomatyczne z krajami bardzo zróżnicowanymi pod wieloma względami

${ }^{32}$ Dzisiaj Stałym Obserwatorem Stolicy Apostolskiej przy ONZ w Nowym Jorku jest abp Francis Assisi Chullikat (od lipca 2010 r.), zaś przy ONZ w Genewie jest abp Silvano Maria Tomasi CS (od czerwca 2003 r.).

${ }^{33}$ Obecnie stałym obserwatorem przy Komitecie Ministrów Rady Europy jest ks. Aldo Giordano.

${ }^{34}$ Od 23 czerwca 2012 urząd nuncjusza Stolicy Apostolskiej pełni abp Alain Paul Lebeaupin.

${ }^{35}$ Por. J. CzAJA, Stolica Apostolska wobec integracji europejskiej, Warszawa 2000, s. 81-100. 
wykształciły nowy profil dyplomacji papieskiej na arenie międzynarodowej. Trzy lata temu, w 2009 r, abp Dominique Mamberti podpisał w Watykanie memorandum o współpracy obustronnej na szczeblu politycznym i kulturalnym z przedstawicielami Ligii Arabskiej. W legatach papieskich widzi się obok przedstawiciela Biskupa Rzymu wysłanników dbających o cele ogólnoludzkie i globalne ${ }^{36}$.

\section{Pojęcie i rodzaje legatów papieskich}

W Kodeksie Jana Pawła II z 1983, jak też i w poprzednim Kodeksie z roku 1917 nie znajdujemy definicji legata papieskiego. Definicja ta została podana w motu proprio Sollicitudo omnium Ecclesiarum papieża Pawła VI, w którym czytamy, że są to „mężowie kościelni posiadający przeważnie święcenia biskupie, którym papież zleca zadanie reprezentowania go na sposób stały w jakimś kraju lub regionie świata" ${ }^{37}$. W definicji wyróżniamy cztery elementy:

1. Mąż kościelny - z określenia wynika, że urząd legata papieskiego może pełnić zarówno osoba duchowna jak i osoba świecka ${ }^{38}$. „Wyrażenie mąż kościelny przede wszystkim wskazuje, iż przedstawiciel Stolicy Apostolskiej powinien wyróżniać się wysokimi kwalifikacjami moralnymi i religijnymi. Przede wszystkim powinien być głęboko przekonany o absolutnej wyższości wartości duchowych nad materialnymi; powinien posiadać odpowiednie wykształcenie i niezbędną formację duchową do wypełnienia tak wysokiego zadania"39.

2. Święcenia biskupie - nawet jeśli w historii wiele osób świeckich było legatami papieskimi i o tym wspomnieliśmy wyżej, to jednak

${ }^{36}$ Por. H. AndRZejCZAK, Teoretyczne i praktyczne aspekty Stolicy Apostolskiej w publicznym prawie międzynarodowym, Roczniki Teologiczno-Kanoniczne, t. 14, z. 5(1967), s. 139-140.

${ }^{37}$ Motu proprio Sollicitudo omnium Ecclesiarum, 29 czerwca 1969, AAS 61(1969), I, 1.

${ }^{38}$ Por. P. Lombardia, Diritti del laico nella Chiesa, Concilium, t. 7, n. 8(1971), S. 161-171.

${ }^{39}$ J. Krukowski, Komentarz do Kodeksu Prawa Kanonicznego, t. II, Ksiega Lud Boży, Pallotinum 2005, s. 207. 
od XVI wieku zanika mianowanie osób świeckich nuncjuszami. Reforma Kościoła i nowe wyzwania wymagały, aby pośrednikami między Rzymem a władcami europejskimi były przede wszystkim osoby duchowne. Dzisiaj widać, że ta zasada przeważa i jest codzienną praktyką Kurii Rzymskiej ${ }^{40}$. Sakra biskupia jest odzwierciedleniem jedności z papieżem i całym Kolegium Biskupim oraz właściwym narzędziem umacniającym legatów papieskich w wykonywaniu ich urzędu. Dlatego papież Paweł VI w swoim motu proprio użył zwrotu osoby kościelne zazwyczaj posiadające święcenia biskupie, a to nie zamyka drogi dla duchownych nieposiadających święceń biskupich oraz wiernych świeckich ${ }^{41}$.

3. Mianowanie przez papieża - Biskup Rzymu ma naturalne i wrodzone prawo do mianowania legatów. To Biskup Rzymu ustanowił ten urząd, a osoba tytulariusza tego urzędu też jest mianowana przez Biskupa Rzymu. Osoba legata papieskiego jest więc nie tylko reprezentantem osobistym Biskupa Rzymu, ale również reprezentantem najwyższego urzędu pasterskiego ${ }^{42}$.

4. Ustanowiony na sposób stały - legat reprezentuje Biskupa Rzymu na sposób stały w różnych krajach i regionach świata wobec kościołów partykularnych i wobec władz państwowych. Ta cecha pojęcia legata akcentuje stabilność urzędu.

Oprócz podstawowych elementów pojęcia legata papieskiego, w prawie kanonicznym spotykamy wymogi, jakie stawia się kandydatom. W Regulaminie Kurii Rzymskiej odnajdujemy te wymogi: ukończenie Papieskiej Akademii Kościelnej w Rzymie, ukończony 33 rok życia oraz stopień naukowy doktora prawa kanonicznego na uniwersytecie papieskim ${ }^{43}$.

${ }^{40}$ Por. M. Flik, La Pontificia Accademia Ecclesiastica nel rinnovamento conciliare, La Civiltà Cattolica 119(1968), s. 531.

${ }^{41}$ Por. W. Góralski, Pojęcie i klasyfikacja legatów papieskich, Kościół i Prawo, n. 12 , s. 90 .

${ }^{42}$ Por. M. Olivieri, Natura e funzioni dei legati pontifici nella storia e nel contesso ecclesiologico del Vaticano II, Città del Vaticano 1982, s. 258.

${ }^{43}$ Por. Regulamin Ogólny Kurii Rzymskiej, 22 lutego 1968, AAS 60(1968), s. 129176. 
Zgodnie z motu proprio Sollicitudo omnium Ecclesiarum istnieją następujące rodzaje legatów papieskich:

1. Delegaci apostolscy, którzy są wysyłani do Kościoła partykularnego jakiegoś kraju lub regionu. Jego misja jest tylko i wyłącznie kościelna. Przedstawicielstwo, którym kieruje nazywa się delegaturą apostolską. Bywa ona ustanawiana $\mathrm{z}$ reguły $\mathrm{w}$ krajach, z którymi Stolica Apostolska nie utrzymuje stosunków dyplomatycznych ${ }^{44}$.

2. W drugiej grupie znajdują się wszyscy ci, którzy zostali wysłani z misją zarówno do Kościoła partykularnego jak i do państw i rządów. Posiadają oni podwójną akredytację ${ }^{45}$. Wśród nich znajdujemy następujących przedstawicieli:

A. Nuncjusz Apostolski - legat papieski w randze ambasadora to jest przedstawiciel dyplomatyczny pierwszej klasy. Stoi na czele stałego i zwyczajnego przedstawicielstwa dyplomatycznego Stolicy Apostolskiej i jest ipso iure dziekanem korpusu dyplomatycznego ${ }^{46}$.

B. Pronuncjusz Apostolski - ten legat papieski jest w randze ambasadora, ale nie pełni funkcji dziekana korpusu dyplomatycznego.

C. Internuncjusz Apostolski - jest legatem papieskim z grupy posłów nadzwyczajnych i ministrów pełnomocnych, należy do drugiej klasy przedstawicieli dyplomatycznych. Jest mianowany wtedy, gdy pomiędzy Stolicą Apostolską a rządem państwa nie ma relacji dyplomatycznych. ${ }^{47}$

Gdy zachodzą określone okoliczności Stolica Apostolska może ustanowić innych przedstawicieli w kategorii:

- delegat apostolski i poseł Stolicy Apostolskiej. Ustanawiani są przy rządach państw, z którymi Stolica Apostolska nie nawiązała jeszcze formalnych stosunków dyplomatycznych ${ }^{48}$.

\footnotetext{
${ }^{44}$ Por. T. Pawluk, Prawo..., s. 163.

${ }^{45}$ Por. M. Francescato, Strutture centrali della Chiesa Universale, w: Il diritto nel mistero della Chiesa, Quaderni di Apollinaris 9(1990), s. 587.

${ }^{46}$ Por. G. Ghirlanda, Il diritto nel mistero della Chiesa, Roma 1990, s. 531.

${ }^{47}$ Tamże, s. 531.

${ }^{48}$ Por. W. Góralski, Pojęcie..., s. 98; T. WŁodarczyk, Konkordaty. Zarys historii ze
} 
- regent, bywa ustanawiany wówczas, gdy przewidywana jest dłuższa nieobecność szefa przedstawicielstwa pierwszej lub drugiej kategorii ${ }^{49}$.

- pełnomocnik do spraw zleconych chargé d'affaires, pełni swoją misję na sposób stały i jest akredytowany przy ministerstwie spraw zagranicznych ${ }^{50}$.

Obok legatów papieskich pełniących swoją misję w sposób stały istnieją reprezentanci do określonych zadań. Mówi o nich Kodeks Prawa Kanonicznego Jana Pawła II, a wcześniejsze motu proprio Pawła VI o nich nie wspominało. Do tej grupy należą:

- legat a latere, specjalny wysłannik reprezentuje Biskupa Rzymu na uroczystościach lub jakimś zgromadzeniu. Zasadniczo bywa nim kardynał.

- wysłannik specjalny, który ma spełnić określone zadanie pastoralne.

- delegat lub obserwator, reprezentuje Stolicę Apostolską przy organizacjach międzynarodowych. W zależności, gdy Stolica Apostolska jest członkiem takiej organizacji, wówczas jest to delegat i ma prawo głosowania. W innym przypadku legat jest tylko obserwatorem, bez prawa do głosowania.

- ablegat, ten przedstawiciel nie ma żadnych uprawnień jurysdykcyjnych, a tylko musi spełnić określone funkcje ceremonialne ${ }^{51}$.

\section{Zadania legatów wobec Kościoła partykularnego}

Zadania legatów papieskich są ściśle określone w motu proprio Sollicitudo omnium Ecclesiarum oraz w Kodeksie Prawa Kanonicznego z 1983r. Na wstępie należy powiedzieć, że obowiązki i zadania legatów papieskich wynikają z rodzaju ich posłannictwa. W tym punkcie zajmiemy się przedstawieniem zadań legata papieskiego wobec Ko-

szczególnym uwzględnieniem XX wieku, Warszawa 1986, s. 499-504.

${ }^{49}$ Por. M. Żurkowski, O duchowieństwie..., s. 185; M. Olivieri, Natura ..., s. 262.

${ }^{50}$ Por. F. Pasternak, Posoborowa ..., s. 48; J. Krukowski, Komentarz..., s. 209.

${ }^{51}$ Por. T. Pawluk, Komentarz ..., s. 164; W. Góralski, Pojęcie..., s. 98. 
ściołów partykularnych. Pierwszoplanową ideą posłannictwa legata papieskiego jest coraz to większe umacnianie więzów łączących Stolicę Apostolską z Kościołami lokalnymi ${ }^{52}$. Ta idea realizuje się w następujących zadaniach:

1. Przesyłanie relacji o stanie Kościoła partykularnego - przedmiotem relacji legackich są wiadomości o warunkach i stanie Kościoła partykularnego. Na podstawie osobistego kontaktu z poszczególnymi diecezjami, z biskupami i innymi osobami. Treścią takiej relacji są wiara, obyczaje i dyscyplina kościelna ${ }^{53}$.

2. Wspieranie biskupów i kontakt z całym episkopatem - legat papieski respektując władzę ordynariuszy pomaga im radą i czynem. Oprócz służebnej roli wobec pojedynczych biskupów powinien utrzymywać relacje z miejscową konferencją biskupów ${ }^{54}$.

3. Przesyłanie listy kandydatów na biskupów oraz wniosków konferencji biskupów w sprawach rozgraniczania diecezji - po przeprowadzonym procesie informacyjnym legat przesyła listę kandydatów na biskupów do kompetentnych Dykasterii Kurii Rzymskiej. Powinien nadto mieć wiadomości o ewentualnej potrzebie erygowania, rozgraniczenia czy zniesienia diecezji lub prowincji kościelnej. Wszystkie opinie powinny być zaopatrzone we własną relację i wnioski legata ${ }^{55}$.

4. Popieranie pokoju, pomyślności narodów i ekumenizmu - te zadania legat wykonuje na płaszczyźnie kościelnej i w duchu chrześcijańskim, tak, aby wspólnota państwowa widziała rzeczywisty wkład Kościoła. Legat papieski powinien promować ekumenizm w porozumieniu z konferencją biskupów ${ }^{56}$.

5. Obrona swobód i praw Kościoła - pomimo że został wysłany do Kościoła partykularnego, to jednak w razie konieczności podejmu-

${ }^{52}$ Por. Motu..., art. IV, n. 1.

${ }^{53}$ Por. J. Krukowski, Zadania Nuncjusza Apostolskiego w Polsce, Kościół i Prawo 11(1993), s. 100.

${ }^{54}$ Por. T. Pawluk, Przedstawicielstwo..., s. 13.

55 Tamże, s. 13.

${ }^{56}$ Por. F. Pasternak, Posoborowa ..., s. 49-50; T. Pawluk, Przedstawicielstwo..., s. 15. 
je działania wobec rządów w zakresie tego, co dotyczy misji Kościoła i swobody jej realizacji we wspólnocie państwowej ${ }^{57}$.

6. Wykonywanie pełnomocnictw oraz innych zadań zleconych - obok zadań wynikających z urzędu legata może on wykonywać inne zadania mu zlecone. Mogą one mieć charakter stały lub czasowy, mogą również być władzą delegowaną do określonych spraw.

\section{Zadania legatów wobec władz państwowych i organizacji międzynarodowych}

W swoich działaniach wobec władz państwowych legat papieski zobowiązany jest do przestrzegania tego wszystkiego, co wynika z prawa dyplomatycznego. Jednak, „legat papieski nie występuje jako przedstawiciel obcego państwa wobec państwa przyjmującego, lecz jako przedstawiciel zwierzchniej władzy Kościoła katolickiego, którego wierni są jednocześnie obywatelami państwa przyjmującego. Jednocześnie reprezentuje on interesy Kościoła powszechnego i Kościoła lokalnego w danym kraju"58. Jego podstawowe zadania to utrzymywanie i ożywianie kontaktów oraz prowadzenie rokowań z władzami danego kraju. Utrzymywanie kontaktów obejmuje zarówno działania formalne jak i ożywianie form kontaktów. Delikatną kwestią jest, aby przy tego typu działaniach nie stworzyć wrażenia ingerowania w wewnętrzne sprawy danego kraju. Legat powinien interesować się każdą płaszczyzną życia wiernych, także porządkiem moralnym w państwie, aby stwarzać owocną współpracę dla dobra wspólnego ${ }^{59}$. Płaszczyzną, na której osiąga się dobrą współpracę jest podpisanie umów, stąd też oddzielnie wyszczególnione zadanie legata to prowadzenie rokowań z rządem. Rokowania, rozmowy, wymiana poglądów na tematy interesujące obie strony może doprowadzić do uregulowania formalnego

${ }^{57}$ Por. J. Krukowski, Zadania ..., s. 101.

${ }^{58}$ J. Krukowski, Komentarz..., s. 213.

${ }^{59}$ Por. T. Pawluk, Przedstawicielstwo..., s. 18-20; T. Pasternak, Posoborowa..., s. 53. 
współpracy poprzez podpisanie umowy. Może to być umowa konkordatowa lub porozumienie o współpracy ${ }^{60}$.

Stolica Apostolska nie tylko aktywnie działa na polu międzynarodowym, ale i jest członkiem wielu organizacji międzynarodowych. Szczególnie zainteresowana jest współpracą z tymi organizacjami międzynarodowymi, których działania dotyczą pokoju i dobra wspólnego wszystkich ludzi. Zostało powiedziane w punkcie drugim o pozycji Stolicy Apostolskiej w prawie międzynarodowym i jej przynależności do wielu organizacji. Zadania legatów papieskich przy organizacjach międzynarodowych to przede wszystkim utrzymywanie kontaktów, poznawanie form działalności i zakresu prac organizacji oraz podejmowanie wspólnych działań na forum organizacji. W sposób generalny zadania te wynikają z Konwencji Wiedeńskiej o Reprezentacji Państw w ich stosunkach z Organizacjami Międzynarodowymi z roku 1975.

Wszyscy delegaci i obserwatorzy Stolicy Apostolskiej akredytowani przy organizacjach międzynarodowych, a także obserwatorzy ad hoc wypełniają swoje zadania, będąc w łączności z legatem papieskim w danym kraju ${ }^{61}$.

Jak wielkie znaczenie ma misja legatów papieskich w świecie i jaką wielką troską Biskup Rzymu otacza swoich przedstawicieli niech świadczy też fakt - ogłoszony w październiku bieżącego roku przez Sekretarza Stanu kardynała T. Bertone - zwołania do Rzymu na czerwiec 2013 r. wszystkich Nuncjuszy, Delegatów Apostolskich i stałych Obserwatorów $^{62}$.

\section{Zakończenie}

W artykule zostało przedstawione zagadnienie uregulowania pozycji prawnej legatów papieskich. Widzimy, że już od początku istnienia Kościoła urząd ten był obecny w Kościele. Do szybko rozrastającej się wspólnoty chrześcijańskiej kierowani są wysłannicy, którzy młodym

\footnotetext{
${ }^{60}$ Por. T. Pawluk, Przedstawicielstwo..., s. 20.

${ }^{61}$ Por. J. Krukowski, Podstawy..., s. 81.

${ }^{62}$ Por. L'Osservatore Romano, 23 październik 2012, www.osservatoreromano.va $\mathrm{z}$ dnia 8 listopada $2012 \mathrm{r}$.
} 
kościołom przekazują polecenia i dekrety apostołów i ich następców. Od IV wieku instytucja legata papieskiego przybiera formy prawne i zostają oni uposażeni w różnorodne narzędzia do spełniania swojej misji.

Na kongresie wiedeńskim w 1815 r. doceniono rolę Stolicy Apostolskiej na arenie międzynarodowej i przyznano nuncjuszom apostolskim prawo pierwszeństwa w korpusie dyplomatycznym. Zaś Kodeks Prawa Kanonicznego z 1917 r. po raz pierwszy w historii w całościowy sposób usystematyzował instytucję legata papieskiego. Po Soborze Watykańskim II papież Paweł VI wydaje motu proprio Sollicitudo omnium Ecclesiarum, w którym precyzuje zadania legatów. Obowiązujący Kodeks Prawa Kanonicznego z 1983 r. systematyzuje całościowo zagadnienie w kanonach 362-367.

W artykule ukazany został aspekt roli jaką pełnią legaci i ich umiejscowienie w prawie międzynarodowym, ze szczególnym uwzględnieniem Konwencji Wiedeńskiej o Stosunkach Dyplomatycznych.

Legaci papiescy zostają wysyłani do władz państwowych, organizacji międzynarodowych oraz do Kościołów partykularnych. W zależności od tego, przy jakim podmiocie pełnią swój urząd takie zadania z tego wynikają. Legaci posiadają przywileje i immunitety z racji pełnionych zadań. Wypełniając zadanie reprezentowania Biskupa Rzymu wyrażają oni jego troskę o jedność Kościoła a także unaoczniają jego zaangażowanie w problemy całej ludzkości.

\section{Legal position of the Legates of the Bishop of Rome}

The paper presents the issue of regulating the legal status of papal legates. We can assume that this body has existed in the Church since its inception. The messengers who conveyed the commands and decrees of the apostles and their successors to the young churches were sent to a rapidly growing Christian community. Since the fourth century, the papal legate institution has taken legal forms, and its representatives have been endowed with legal instruments to fulfill their mission.

In 1815, at the Congress of Vienna, the role of the Holy See was appreciated in the international arena, and apostolic nuncios were ap- 
pointed as deans in the diplomatic corps. The Code of Canon Law of 1917 systematised the institution of the papal legate in a comprehensive manner for the first time in history. After the Second Vatican Council, Pope Paul VI issued the motu proprio "Sollicitudo omnium Ecclesiarum, which specifies the legates' assignments. The mandatory Code of Canon Law of 1983 systematises the whole issue in canons 362-367.

The article shows the aspect of the legates' role and their position in the international arena, with particular reference to the Vienna Convention on Diplomatic Relations.

Papal legates are sent to state authorities, international organisations and particular Churches. They perform their tasks, depending on where they hold their office. In addition to their tasks, the legates have privileges and immunities required by their jobs. While completing the role of representing the Bishop of Rome, they express their concern for the unity of the Church and elucidate their involvement in the problems of humanity. 